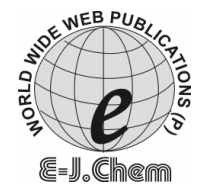

http://www.e-journals.net
ISSN: 0973-4945; CODEN ECJHAO

E-Journal of Chemistry 2009, 6(3), 809-813

\title{
Development of Difference Spectroscopic Method for the Estimation of Balsalazide in Bulk and in Formulation
}

\author{
K.ANANDAKUMAR ${ }^{*}$, NAGESWARARAO PACHA, J.SAMINATHAN, \\ R. SUBATHRAI and KUMARASAMY GANDLA
}

Department of Pharmaceutical Analysis,

Adhiparasakthi College of Pharmacy, Melmaruvathur - 603 319, Kanchipuram Dist., Tamilnadu, India.

anandkarunakaran@gmail.com

Received 6 November 2008; Revised 19 January 2009; Accepted 5 February 2009

\begin{abstract}
A simple, precise and accurate difference spectroscopic method has been developed for the estimation of balsalazide in bulk and in pharmaceutical dosage form. The proposed method is based on the principle that balsalazide can exhibit two different chemical forms in basic and acidic medium that differ in the absorption spectra in basic and acidic medium. Since the drug was freely soluble in distilled water, a stock solution $(1 \mathrm{mg} / \mathrm{mL})$ was prepared with distilled water. Further dilution was made by using $0.1 \mathrm{M}$ sodium hydroxide and $0.1 \mathrm{M}$ hydrochloric acid separately. The maxima and minima in the difference spectra of balsalazide were at $460 \mathrm{~nm}$ and $354 \mathrm{~nm}$, respectively. Difference in absorbance between these maxima and minima was calculated to find out the amplitude. This amplitude was plotted against concentration. Beer's law is valid in the concentration range of $2-20 \mu \mathrm{g} / \mathrm{mL}$. The results of analysis have been validated statistically and by recovery studies.
\end{abstract}

Keywords: Balsalazide, Difference Spectroscopy, Estimation, Pharmaceutical dosage form.

\section{Introduction}

Balsalazide (BSZ) ${ }^{1-3}$ a new drug, which is chemically (E)-5-[[-4-[[(2-carboxyethyl) amino] carbonyl] phenyl] azo]-2-hydroxybenzoic acid, disodium salt, dihydrate. BSZ is a prodrug is used for Crohn's disease (ulcerative colitis) is delivered intact to the colon by bacterial azo reduction to release equimolar quantities of mesalamine (5-aminosalicylic acid) an active portion of the molecule and 4-aminobenzoyl-(beta)-alanine ${ }^{3-12}$. BSZ is not official in any 
pharmacopoeia. Literature survey revealed that there are so many methods were reported for the pharmacokinetic study ${ }^{13-19}$ and pharmacological study ${ }^{20-22}$ of BSZ and a LC-MS ${ }^{23}$ method was reported for the estimation of BSZ in human plasma. But there is no method was reported for the estimation of BSZ in bulk drug and in formulations. Hence the present work aims to develop a simple, precise, accurate and validated difference spectroscopic method for the estimation of BSZ in bulk and in capsule dosage form.

\section{Experimental}

Shimadzu UV-1700 UV/VIS spectrophotometer with $1 \mathrm{~cm}$ matched quartz cells was used for spectral and absorbance measurements. BSZ was as a gift sample from Krebs Pharma, Chennai. The commercially available capsules were procured from the local market. All the chemicals used were of AR grade.

Freshly prepared $0.1 \mathrm{M}$ sodium hydroxide and $0.1 \mathrm{M}$ hydrochloric acid and distilled water were used in the present investigation. The commercially available marketed tablet balacol capsules (Torrent Pharmaceuticals Ltd., Ahmedabad) containing $750 \mathrm{mg}$ of BSZ was used and it was procured from the local market.

\section{Preparation of standard stock solution}

$50 \mathrm{mg}$ of BSZ was weighed accurately and dissolved in distilled water and made up the volume to $50 \mathrm{~mL}$ in a volumetric flask. The solution was further diluted with $0.1 \mathrm{M}$ hydrochloric acid and $0.1 \mathrm{M}$ sodium hydroxide separately to get the concentration of $200 \mu \mathrm{g} / \mathrm{mL}$ (working standards). Different aliquots were taken from their working standards and diluted with $0.1 \mathrm{M}$ hydrochloric acid and $0.1 \mathrm{M}$ sodium hydroxide separately to prepare a series of concentrations from $2-20 \mu \mathrm{g} / \mathrm{mL}$ as reference and test solutions, respectively. Difference spectrum was recorded by placing BSZ in $0.1 \mathrm{M}$ hydrochloric acid in reference cell and $0.1 \mathrm{M}$ sodium hydroxide in sample cell. Difference in absorbance between $354 \mathrm{~nm}$ and $460 \mathrm{~nm}$ was calculated to find out the amplitude. The calibration curve was prepared by plotting amplitude versus concentration.

\section{Application of the proposed procedure for the determination of dosage form}

Marketed capsule formulation was used for analysis. Twenty capsules were weighed and their average net weight was calculated. The capsules were emptied and the powder was made to a fine powder. The powder equivalent to $50 \mathrm{mg}$ of BSZ was weighed and transferred in to $50 \mathrm{~mL}$ volumetric flask. Dissolved in distilled water and made up to the volume with the same. The solution was filtered through Whatman filter paper No.41. From the stock solution, $10 \mu \mathrm{g} / \mathrm{mL}$ solutions were prepared separately by using $0.1 \mathrm{M}$ hydrochloric acid and $0.1 \mathrm{M}$ sodium hydroxide. The amplitude was calculated by measuring the absorbance of the equimolar concentrations at maxima and minima in the difference spectrum. The amount of BSZ was calculated. The procedure was repeated for six times to perform precision.

\section{Recovery studies}

The accuracy of the proposed method was examined by determining the recovery of the drug by standard addition technique. To the preanalysed formulation, a known amount of BSZ raw material was added in different concentrations viz., 25\%, 50\%, $75 \%$ and $100 \%$ in both the reference and sample solutions. The procedure was repeated as per the analysis of formulation. The amplitude was calculated and the amount of BSZ recovered was determined. This was repeated for six times. 


\section{Results and Discussion}

A simple, precise, accurate difference spectrophotometric method has been developed for the estimation of BSZ in pure and in formulations. In this method, the measured value is the difference in absorbance $(\Delta \mathrm{A})$ between two equimolar solutions of the analyte in different chemical forms which exhibit different spectral characteristics. The difference spectrum of BSZ in $0.1 \mathrm{M} \mathrm{NaOH}$ was recorded by taking BSZ in $0.1 \mathrm{M} \mathrm{HCl}$ solution as blank. The difference spectrum showed that the maxima at $460 \mathrm{~nm}$ and minima at $354 \mathrm{~nm}$. (Figure 1).

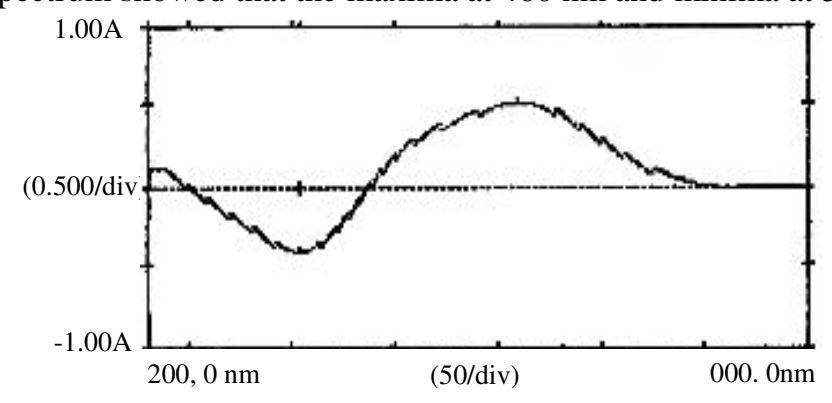

Figure 1. Difference spectrum of BSZ $(10 \mu \mathrm{g} / \mathrm{mL}$ solution of BSZ in $0.1 \mathrm{M} \mathrm{HCl}$ was taken as blank and the same concentration of drug in $0.1 \mathrm{M} \mathrm{NaOH}$ as sample).

In alkaline solution, drug shows more intense peak than acidic peak. Therefore $\Delta \mathrm{A}$ is positive. Six point calibration graphs were constructed covering a concentration range $2-20 \mu \mathrm{g} / \mathrm{mL}$. Six independent determinations were performed at each concentration. Linear relationships between amplitude of maxima and minima of difference spectra versus the corresponding drug concentrations were observed. The standard deviation of the slope and intercept were low. The correlation coefficient $\left(\mathrm{r}^{2}\right)$ exceeded 0.999 . The calculated $\mathrm{F}$ value equal to 11419.34 is highly significant. A student's $t$ - test was performed to determine whether the experimental intercept (c) of the regression equation was not significantly different from the theoretical zero value. It concerns the comparison of $t=\mathrm{c} / \mathrm{s}_{\mathrm{c}}$, where $\mathrm{c}$ is the intercept of regression equation and $\mathrm{s}_{\mathrm{c}}$ is the standard deviation of $\mathrm{c}$, with tabulated data of the $t$ distribution. As the calculated $t$ - value $(t=0.573)$ does not exceed to $(0.01 \%) 3.365$, the intercept of regression equation is not significantly different from zero. The LOD and LOQ were calculated (Table 1).

Table 1. Optical characteristics of balsalazide by difference spectroscopy.

\begin{tabular}{lc}
\hline \multicolumn{1}{c}{ Parameters } & Difference spectroscopic method \\
\hline$\lambda$ max, $\mathrm{nm}$ & $460^{\mathrm{a}}, 354^{\mathrm{b}}$ \\
Beer-lamberts law limit, $\mu \mathrm{g} / \mathrm{mL}$ & $2-20$ \\
Molar absorptivity, mol. $\mathrm{L}^{-1} \mathrm{~cm}^{-1}$ & $5.0314 \times 10^{4}$ \\
Regression equation, $\mathrm{Y}=\mathrm{a}+\mathrm{bx}$ & \\
Slope (b) & 0.1143 \\
Intercept (a) & 0.00683 \\
Correlation coefficient (r) & 0.9990 \\
$\%$ Relative standard deviation, $\mathrm{n}=6$ & 0.2783 \\
Sandell's sensitivity $\left(\mu \mathrm{g} / \mathrm{cm}^{2} / 0.001 \mathrm{AU}\right)$ & 0.0087 \\
LOD, $\mu \mathrm{g} / \mathrm{mL}$ & 0.0755 \\
LOQ $\mu \mathrm{g} / \mathrm{mL}$ & 0.2290 \\
\hline
\end{tabular}

$a$ and $b$ are the maxima and minima, respectively. 
The repeatability study $(n=6)$ was carried out and the amount of BSZ was found to be $99.13 \pm 0.273$ with $\%$ RSD value of 0.276 . It showed that the method was precise and the equipment used for the study worked correctly for the developed analytical method and being highly repetitive (Table 2). For the intermediate precision, a study carried out by the same analyst working on three times in the same day and three consecutive days indicated the \% RSD of 0.3776 and 0.9748 for inter day and intraday analysis, respectively. Both the percentage RSD values were of below $2 \%$, indicated that the intermediate precision was confirmed (Table 3). All the formulations contain excipients, lubricating agents and binders which are added along with the active drug constituents. These substances may cause some interference during the estimation of the active drug constituents. This was determined by accuracy. The data for accuracy were expressed in terms of percentage recoveries of BSZ in the real samples. These results are summarized in Table 4 . The mean recovery data of BSZ in real sample were within the range of $98.22 \%$ and $101.58 \%$, mean \% RSD was 1.439 , satisfying the acceptance criteria for the study. All the above validation parameters were performed as per ICH guidelines $^{24-25}$.

Table 2. Analysis of tablet formulation.

\begin{tabular}{cccccccc}
\hline $\begin{array}{c}\text { S. } \\
\text { No }\end{array}$ & $\begin{array}{c}\text { Labeled amount, } \\
\text { mg/capsule }\end{array}$ & $\begin{array}{c}\text { Amount } \\
\text { found, mg }\end{array}$ & $\begin{array}{c}\% \\
\text { Label claim }\end{array}$ & Average & S.D. & \%RSD & S.E \\
\hline 1 & 750 & 745.85 & 99.45 & & & & \\
2 & 750 & 745.82 & 99.44 & & & & \\
3 & 750 & 743.65 & 99.15 & $99.13 \%$ & 0.273 & 0.276 & 0.111 \\
4 & 750 & 742.09 & 98.95 & & & & \\
5 & 750 & 742.93 & 99.05 & & & & \\
6 & 750 & 740.75 & 98.76 & & & & \\
\hline
\end{tabular}

Table 3. Intraday and Interday analysis of formulation.

\begin{tabular}{ccccc}
\hline \multirow{2}{*}{ S.No. } & \multicolumn{2}{c}{ \% Label Claim } & \multicolumn{2}{c}{ \% RSD } \\
\cline { 2 - 3 } & Intraday $^{*}$ & Interday $^{*}$ & Intraday $^{*}$ & Interday $^{*}$ \\
\hline 1. & 98.92 & 98.26 & & \\
2. & 99.64 & 100.17 & 0.3776 & 0.9748 \\
3. & 99.10 & 98.96 & & \\
\cline { 2 - 3 } & 99.22 & 99.13 & & \\
\hline
\end{tabular}

Table 4. Recovery studies.

\begin{tabular}{ccccccccc}
\hline S.No. & $\begin{array}{c}\text { Amount } \\
\text { present } \\
\mu \mathrm{g} / \mathrm{mL}\end{array}$ & $\begin{array}{c}\text { Amount } \\
\text { added, } \\
\mu \mathrm{g} / \mathrm{mL}\end{array}$ & $\begin{array}{c}\text { Amount } \\
\text { found, } \\
\mu \mathrm{g} / \mathrm{mL}\end{array}$ & $\begin{array}{c}\text { Amount } \\
\text { recovered, } \\
\mu \mathrm{g} / \mathrm{mL}\end{array}$ & $\begin{array}{c}\text { Percentage } \\
\text { recovery, } \%\end{array}$ & S.D. & $\begin{array}{c}\% \\
\text { RSD }\end{array}$ & S.E. \\
\hline 1 & 5.031 & 2.53 & 7.814 & 2.57 & 101.58 & & & \\
2 & 5.031 & 5.06 & 10.352 & 4.97 & 98.22 & & & \\
3 & 5.031 & 7.59 & 12.894 & 7.46 & 98.29 & 1.434 & 1.439 & 0.585 \\
4 & 5.031 & 10.12 & 15.431 & 10.16 & 100.39 & & & \\
5 & 5.031 & 12.65 & 17.965 & 12.64 & 99.92 & & & \\
\hline
\end{tabular}




\section{Conclusion}

The proposed method is simple, accurate, precise and selective for the estimation of BSZ in bulk and in capsule dosage forms. The method is economical, rapid and do not require any sophisticated instruments contrast to chromatographic method. Hence it can be effectively applied for the routine analysis of BSZ in bulk and in capsule dosage forms.

\section{Acknowledgements}

The authors wish to thank Krebs Pharma, Chennai for providing the gift sample of BSZ. Also thankful to Arulthiru Amma and Thirumathi Amma, Adhiparasakthi charitable medical, educational, cultural trust for providing the necessary facilities to carry out the research work.

\section{References}

1. CIMS, CMP Medica India Private Limited, Bangalore, 2006, 13, 42.

2. Anthony C Moffer, David Osselton M and Brain Widdop, Clarke's analysis of drugs and poisons $3^{\text {rd }}$ Ed., Royal pharmaceutical society of Great Britain, 2004, II, 667.

3. Maryadale J O' Neil, Patricia E Heckleman, Cherie B Koch and Kristin J Roman, The Merck Index, $14^{\text {th }}$ Ed Merck and Co Inc, White House Station, NJ, USA, 2006, 945, 160.

4. Giaffer M H, Holdsworth C D and Lennard Jones J E, Aliment Pharmacol Ther., 2000, 15(10), 1549-1554.

5. Green J R, Swan C H and Rowlinson A, Aliment Pharmacol Ther., 2004, 19(2),179-189.

6. Green J R B, Lobo A J and Holdsworth C D, Gastroenterology, 2000, 98(1), 216-219.

7. Muijser R B, Drugs, 2002, 62.

8. Patil S A and Moss A C, J Clin Gastroenterol., 2008, 42, 119.

9. Tursi A, Pharmacol Res., 2008, 58, 190.

10. Lakatos P L and Lakatos L, Pharmaco Res., 2008, 58(3-4), 190-195.

11. Rahimi R, Nikfar S, Rezaie A and Abdollahi M, Reprod Toxicol., 2008, 25, 271.

12. Ragunath K, Williams J G, BMJ, 2001, 323, 489.

13. Christensen L A and Jacobsen B A, Aliment Pharmacol Ther., 1988, 2, 237.

14. Hussain F N, Ajjan R A and Riley S A, Expert Rev Gastroenterol Hepatol., 2008, 2, 177.

15. Sandborn W J, Hanauer S B and Buch A, Aliment Pharmacol Ther., 1998, 1089.

16. Hussain F N, Ajjan R A and Riley S A, British J Clin Pharmacol., 2000, 49, 323-330.

17. Sandborn W J, Indian J Gastroenterol., 2005, 24, 263.

18. Tromm A, Griga T and May B, Gastroenterology, 1999, 117, 1513.

19. Klotz U, Br Med J., (Clin Res Ed.,). 1984, 288, 1652.

20. Sandborn W J and Hanauer S B, Am J Gastroenterol., 2002, 97, 3078.

21. Kimura I, Kawasaki M, Nagahama S, Matsuda A, Kataoka M and Kokuba Y, Arzneimittelforschung, 1998, 48, 1007.

22. Kumamoto T, Matsuda A, Kataoka M and Kokuba Y, Nippon Yakurigaku Zasshi, 1997, 109, 85.

23. Kimura I, Nagahama S, Kawasaki M, Kataoka M and Sato M, Aliment Pharmacol Ther., 1992, 6, 647.

24. Shrinivas S Savale, Rathnakar Palarapu, Chandramohan Kandasamy, Viny Sam, Anu Mary John, Sundar Ganesan and Arvind A S, Aliment Pharmacol Ther., 2004, 19, 1089.

25. Code Q2A Text on validation of analytical procedures Step-3, Consensus Guideline, ICH Harmonized Tripartite guidelines. 1996.

26. Code Q2B Validation of analytical Procedures-Methodology Step-4, Consensus Guideline, ICH Harmonized Tripartite guidelines, 1996. 


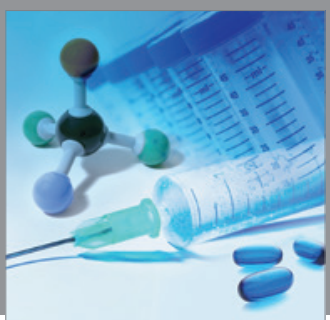

International Journal of

Medicinal Chemistry

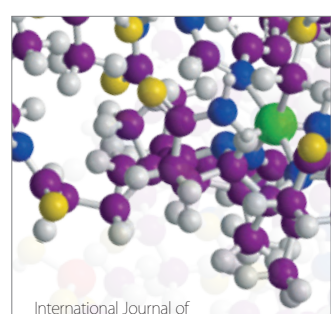

Carbohydrate Chemistry

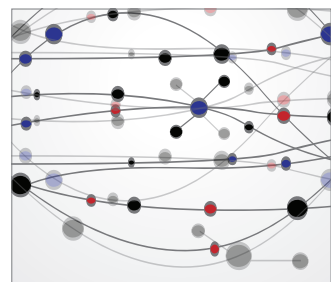

The Scientific World Journal
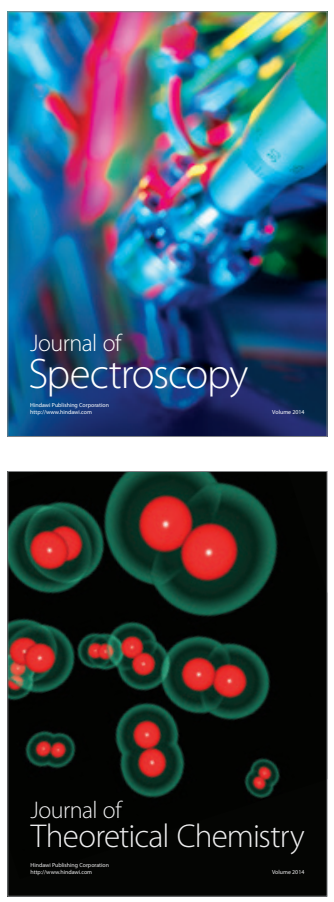
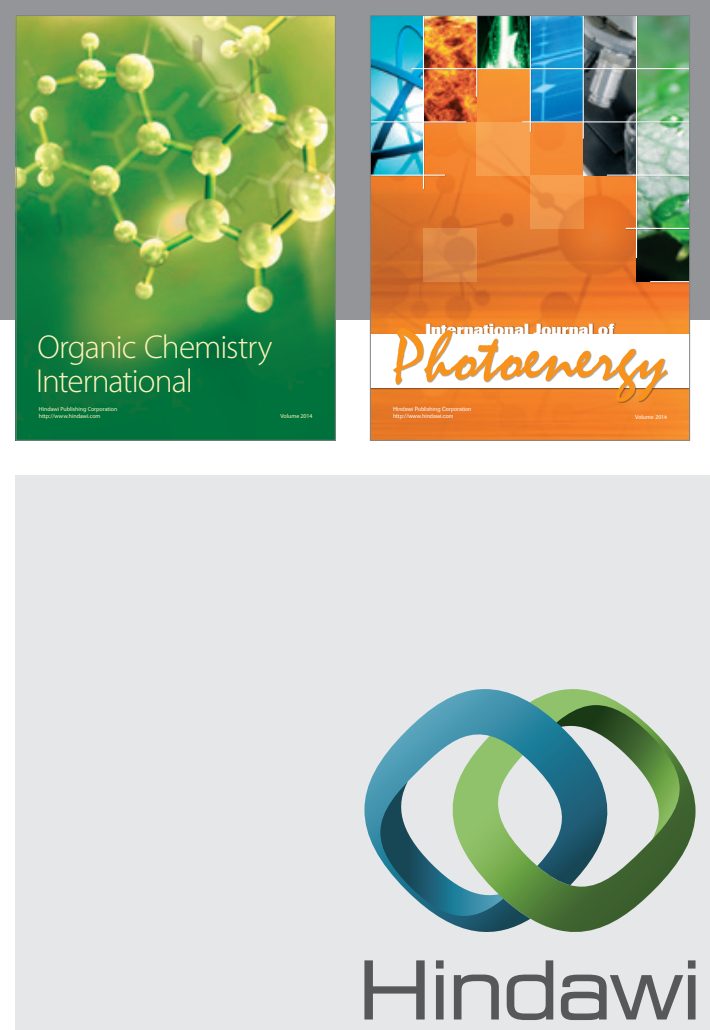

Submit your manuscripts at

http://www.hindawi.com
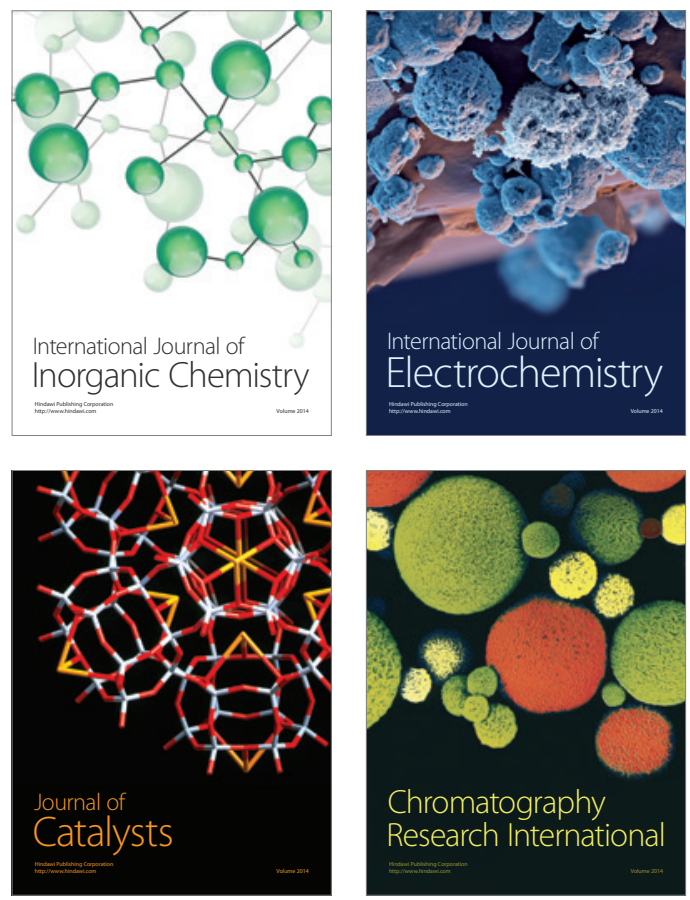
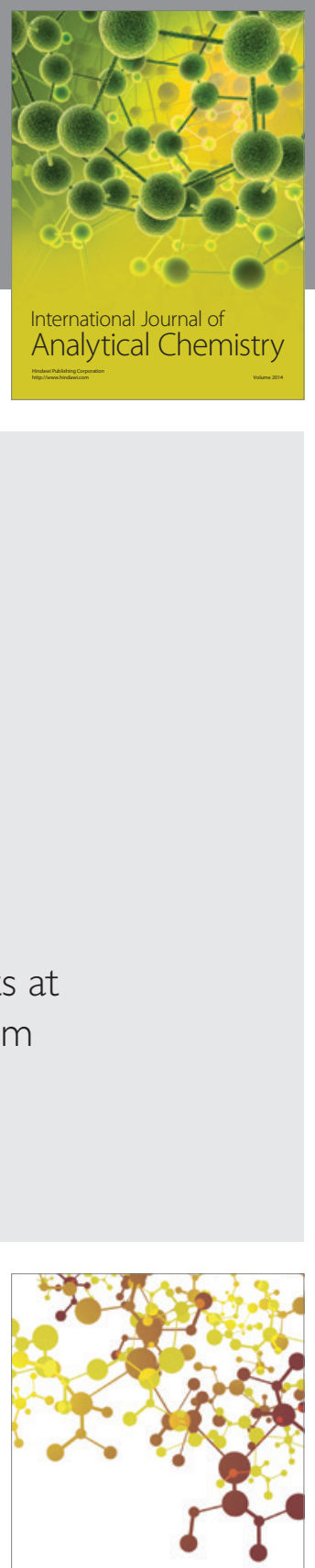

Journal of

Applied Chemistry
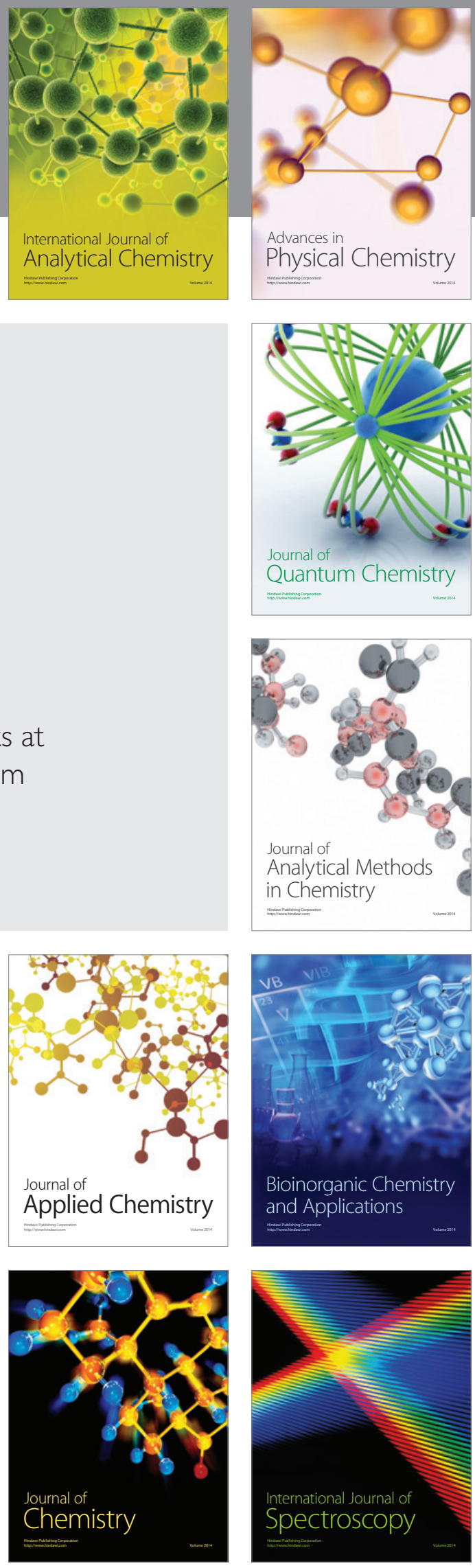